\title{
Comparative study on the microbiological quality of vegetables collected from local markets and super shops of Dhaka city
}

\author{
Mofijur Rahman Mamum, Kamal Kanta Das*, Md. Sohel Rana, Halimatus Sadia Tanim and \\ Farahnaaz Feroz
}

Department of Microbiology, Stamford University Bangladesh, 51, Siddeswari Road, Dhaka-1217, Bangladesh

Received 06 October 2021/Accepted 21 November 2021

\begin{abstract}
Vegetables are major source of vitamins and fibers but presence of pathogens in salad vegetables can cause outbreak of diseases. Several studies have been conducted on commonly consumed vegetables so far to detect the level of microbial contamination. However, few of them compare the microbial quality of local and super shop vegetables. The present study was conducted for microbiological assessment and comparing four types of vegetables collected from two different market conditions. In this study, Green chili (Capsicum frutescens L.), Tomato (Solanum lycopersicum), Coriander (Coriandrum sativum) and Lady's finger (Abelmoschus esculentus) were analyzed to determine Total Viable Bacterial (TVB) Counts, Total Fungal (TF) Counts, Total Coliform Counts (TCC), Total Fecal Coliform (TFC) Counts and occurrence of Staphylococcus aureus, Pseudomonas spp., Listeria spp., Bacillus spp., Salmonella spp., and Vibrio spp. Among these microorganisms, Klebsiella spp. and Pseudomonas spp. were significantly present in coriander of both local market and super shop. All pathogenic bacteria and fungi were found in huge amounts in the vegetable samples of the local market. Although some pathogenic bacteria and fungi were also found in the same samples of the super shop, relatively lower than the local market's vegetables. In conclusion, contamination in collected vegetable samples were not acceptable but comparatively higher load in local market samples indicated that the hygienic condition in these markets is not sufficiently maintained.
\end{abstract}

Keywords: Food safety, Vegetables, Food contamination, Consumer's risk, Super shop.

\section{INTRODUCTION}

Vegetables are commonly consumed all over the world due to their nutritional value and their availability. Also, the people are now more careful than previous days and follow healthy lifestyle which has boosted up the trend of consumption of raw vegetables and food globally (1-3). Vegetables and food are low fat and low energy-dense foods besides containing varieties of vitamins, minerals, and other phytochemicals that help to prevent many serious diseases like cardiovascular disease; cancer; diabetes; and osteoporosis (4-6). However, along with nutritional value consumption of raw or undercooked vegetables can cause many food-borne diseases (1, 713). Growth of microorganisms on vegetables depends on various intrinsic and extrinsic factors such as $\mathrm{pH}$, temperature, moisture, acidity, water activity, oxygen concentration, redox potential, etc. (14). Generally, vegetables contain varieties of fungi and bacteria including Aspergillus spp., Escherichia coli, Klebsiella spp., Staphylococcus aureus, Bacillus spp., Pseudomonas spp., Listeria spp., Salmonella spp., Shigella spp., Vibrio spp. etc (7, 10, 13, 15). These microorganisms cause many food-borne diseases such as food poisoning, diarrhea, dysentery, cholera, etc. (7, 10, 13). The sources of microorganisms in vegetables can be identified as air, water, the soil of cultivated land, pots in where vegetables are kept, shopkeeper's hands, hair, dresses, etc. (16-20).

Like other countries, ranges of vegetables are available in Bangladesh which are and also popular to Bangladeshi people. However, poor processing practices, post-harvest handling using non-sterile, use of poor quality water for washing and faulty packaging and transportation system make them more susceptible to microbial contamination (23). In Dhaka city, vegetables are sold in local markets as well as from super shops. People prefer local markets for purchasing vegetables for several reasons such as, low price, easily accessible locations and vegetables seem fresh, etc. However, super shops are becoming popular day by day in Dhaka city because vegetables and other food items are kept in a chiller in hygienic conditions which are properly maintained in local market (10).

Generally, local markets are located in open places whereas super shops are placed in closed building. Local markets are congested and dirty whereas super shop is not congested but much cleaner. Water, air, floor, vegetable pots are much clean in super shops than local markets. Furthermore, many studied reported that preservation systems and hygienic practice are very decent in super shops comparing to the local markets $(36,37)$.

Considering all these facts, this study was designed 
to investigate and compare the microbiological quality of common vegetable samples from local and super markets of Dhaka city.

\section{MATERIALS AND METHODS}

Samples and Sampling Sites. Total 24 vegetable samples of four categories (Lady's finger, Coriander, Green chili and Tomato) were collected from three local markets (Karwan Bazar, Malibag, Shantinagar) and three super shops (near Bailey Road) early in the morning and transported to the laboratory as soon as possible according to the standard methods suggested by American Public Health Association (21)

Microbiological analysis of sample. Ten grams of each of the vegetable sample was homogenized in $90 \mathrm{ml}$ saline and diluted up to $10^{-6}$ following the standard methods then the volume of $0.1 \mathrm{ml}$ from each sample suspension was spread onto nutrient agar (NA) and incubated at $37^{\circ} \mathrm{C}$ for 24 hours for enumerating total viable bacteria (TVB). Sabouraud dextrose agar (SDA) (Oxoid Ltd., Hampshire, England) was inoculated followed by incubation a $25^{\circ} \mathrm{C}$ for 48 hours for isolation of fungi. On the other hand, for the isolation of coliform bacteria (Escherichia coli, Klebsiella spp.), $0.1 \mathrm{ml}$ of each sample suspension was spread over MacConkey (Oxoid Ltd., Basingstoke, Hampshire, England) agar and incubated at $37^{\circ} \mathrm{C}$ for 24 hours $(7,10,22)$. For enumerating total fecal coliform, $0.1 \mathrm{ml}$ of each sample suspension was spread onto membrane fecal coliform (MFC) (Oxoid Ltd., Hampshire England) agar and incubated at $45^{\circ} \mathrm{C}$ for 24 hours. $0.1 \mathrm{ml}$ of each sample suspension was spread on mannitol salt agar (MSA) (Oxoid Ltd., Hampshire, England) for the estimation of Staphylococcus aureus, and the plates were incubated at $37^{\circ} \mathrm{C}$ for 24 hours. For the estimation of starch hydrolyzing bacteria (Bacillus spp.), $0.1 \mathrm{ml}$ of each sample suspension was spread onto starch agar (SA) (Oxoid Ltd., Hampshire, England) and incubation at $37^{\circ} \mathrm{C}$ for 24 hours (23-24)

For the enumeration of Pseudomonas spp., $0.1 \mathrm{ml}$ of each sample suspension was spread onto Pseudomonas agar (Oxoid Ltd., Hampshire, England) and plates were incubated at $37^{\circ} \mathrm{C}$ for 24 hours. For the estimation of Listeria spp., $0.1 \mathrm{ml}$ of each sample suspension was spread onto Listeria identification agar (LA) (Oxoid Ltd., Hampshire, England) containing Listeria supplements and the plates were incubated at $37^{\circ} \mathrm{C}$ for 24 hours (2324).
Enrichment of Salmonella spp., Shigella spp. and Vibrio spp. The in vitro cultivation of the species of Salmonella, Shigella and Vibrio often appears difficult or with faulty results (false-negative) due to their viable but nonculturable (VBNC) attributes (32-33). Therefore, enrichment was used prior to isolating these bacteria $(7,24)$. Enrichment was performed for Salmonella spp. and Shigella spp., in the selenite cysteine broth (SCB). $1 \mathrm{ml}$ of homogenized sample suspension was transferred to SCB followed by incubation at $37^{\circ} \mathrm{C}$ for 4 hours and serially diluted up to $10^{-5}$, and from $10^{-3}$ dilution, $0.1 \mathrm{ml}$ was spread onto Salmonella Shigella (SS) agar (Hi media, India) followed by the incubation at $37^{\circ} \mathrm{C}$ for 24 hours. For the enrichment of Vibrio spp., $0.1 \mathrm{ml}$ of the homogenized sample suspension was transferred to $10 \mathrm{ml}$ alkaline peptone water (APW) and incubated at $37^{\circ} \mathrm{C}$ for 4 hours and serial dilutions were made up to $10^{-5}$ and from $10^{-3}$ dilution, $0.1 \mathrm{ml}$ was spread onto TCBS (Oxoid Ltd., Hampshire, England) agar followed by the incubation at $37^{\circ} \mathrm{C}$ for 24 hours $(23,24)$. Finally, representative isolates were confirmed by the number of biochemical tests, like the triple sugar iron (TSI), motility indole urease (MIU), methyl-red (MR), Voges-Proskauer (VP), citrate utilization, catalase, and oxidase tests (23-24)

\section{RESULTS}

Incidence of bacteria and fungi in vegetable samples. In our investigation, contamination was found in most of the samples (Lady Finger, Coriander, Green Chili, and Tomato), the total viable bacteria count (TVBC) was observed within a range of $10^{5}$ to $10^{7} \mathrm{cfu} / \mathrm{g}$ in all samples collected from local markets and super shops. The highest TVBC is observed in Lady Finger $\left(3.2 \times 10^{7} \mathrm{cfu} / \mathrm{g}\right)$ and Coriander $\left(2.6 \times 10^{6}\right.$ $\mathrm{cfu} / \mathrm{g}$ ) also showed the maximum total fungal count, both samples are collected from local shops (Table 1). In the case of local shop samples, most of them were contaminated by all pathogenic bacteria. Where

Table 1. Microbial proliferation of vegetables collected from local markets.

\begin{tabular}{|c|c|c|c|c|c|c|c|c|c|c|c|}
\hline Sample & TVB & TF & $\begin{array}{c}\text { Escherich } \\
\text { ia coli }\end{array}$ & $\begin{array}{c}\text { Klebsiella } \\
\text { spp. }\end{array}$ & TFC & $\begin{array}{l}\text { Staphyloco } \\
\text { ccus spp. }\end{array}$ & $\begin{array}{c}\text { Bacillu } \\
\text { s spp. }\end{array}$ & $\begin{array}{l}\text { Pseudom } \\
\text { onas spp. }\end{array}$ & $\begin{array}{c}\text { Listeria } \\
\text { spp. }\end{array}$ & $\begin{array}{c}\text { Salmonell } \\
\text { a spp. }\end{array}$ & $\begin{array}{c}\text { Vibrio } \\
\text { spp. }\end{array}$ \\
\hline Lady's Finger & $3.2 \times 10^{7}$ & $1.5 \times 10^{6}$ & $2.6 \times 10^{3}$ & $8.2 \times 10^{2}$ & $4.0 \times 10^{2}$ & $1.1 \times 10^{3}$ & $2.6 \times 10^{2}$ & 0 & $1.8 \times 10^{2}$ & $8.5 \times 10^{2}$ & 0 \\
\hline Coriander & $2.9 \times 10^{5}$ & $2.6 \times 10^{6}$ & $3.0 \times 10^{3}$ & $9.0 \times 10^{2}$ & $8.0 \times 10^{2}$ & $1.9 \times 10^{3}$ & $1.4 \times 10^{2}$ & $2.1 \times 10^{2}$ & $2.4 \times 10^{2}$ & 0 & 0 \\
\hline Green Chili & $2.9 \times 10^{7}$ & $1.6 \times 10^{5}$ & $4.8 \times 10^{3}$ & $2.5 \times 10^{2}$ & 0 & $6.8 \times 10^{3}$ & $4.8 \times 10^{2}$ & 0 & $1.3 \times 10^{2}$ & $2.8 \times 10^{2}$ & 0 \\
\hline Tomato & $1.9 \times 10^{7}$ & $1.1 \times 10^{5}$ & $3.2 \times 10^{3}$ & $1.4 \times 10^{2}$ & 0 & $6.4 \times 10^{3}$ & $4.0 \times 10^{2}$ & $2.8 \times 10^{2}$ & $1.7 \times 10^{2}$ & 0 & 0 \\
\hline
\end{tabular}

Note: TVB-Total Viable Bacteria, TF-Total Fungus, TFC-Total Fecal Coliform.

Table 2. Microbial proliferation of vegetables collected from super shops.

\begin{tabular}{|c|c|c|c|c|c|c|c|c|c|c|c|}
\hline Sample & TBV & TF & $\begin{array}{c}\text { Escherich } \\
\text { ia coli }\end{array}$ & $\begin{array}{c}\text { Klebsiella } \\
\text { spp. }\end{array}$ & $\begin{array}{c}\text { TF } \\
\text { C }\end{array}$ & $\begin{array}{c}\text { Staphylococc } \\
\text { us spp. }\end{array}$ & $\begin{array}{c}\text { Bacillus } \\
\text { spp. }\end{array}$ & $\begin{array}{c}\text { Pseudomon } \\
\text { as spp. }\end{array}$ & $\begin{array}{c}\text { Listeria } \\
\text { spp. }\end{array}$ & $\begin{array}{c}\text { Salmonell } \\
a \text { spp. }\end{array}$ & $\begin{array}{c}\text { Vibrio } \\
\text { spp. }\end{array}$ \\
\hline Lady Finger & $2.0 \times 10^{6}$ & $1.0 \times 10^{4}$ & $2.5 \times 10^{2}$ & 0 & 0 & $2.0 \times 10^{4}$ & 0 & $6.5 \times 10^{2}$ & $2^{2} \quad 0$ & 0 & 0 \\
\hline Coriander & $3.5 \times 10^{6}$ & $1.0 \times 10^{4}$ & $3.0 \times 10^{2}$ & $8.0 \times 10^{2}$ & 0 & $4.0 \times 10^{2}$ & 0 & $7.6 \times 10^{3}$ & 0 & 0 & 0 \\
\hline Green Chili & $7.5 \times 10^{6}$ & 0 & 0 & 0 & 0 & $1.7 \times 10^{2}$ & 0 & $8.0 \times 10^{3}$ & 0 & 0 & 0 \\
\hline Tomato & $1.2 \times 10^{6}$ & 0 & 0 & 0 & 0 & $2.0 \times 10^{2}$ & 0 & $8.0 \times 10^{3}$ & 0 & 0 & 0 \\
\hline
\end{tabular}

Table 3. Confirmative biochemical tests for the isolates.

\begin{tabular}{|c|c|c|c|c|c|c|c|c|c|c|}
\hline \multirow{2}{*}{$\begin{array}{l}\text { Assumed } \\
\text { Organism }\end{array}$} & \multicolumn{4}{|c|}{ TSI } & \multirow[b]{2}{*}{ 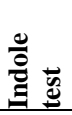 } & \multirow[b]{2}{*}{$\underline{\Sigma}$} & \multirow[b]{2}{*}{$\begin{array}{l}\overrightarrow{v_{0}} \\
\frac{5}{5} \\
\end{array}$} & \multirow{2}{*}{ 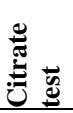 } & \multirow{2}{*}{ 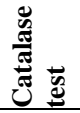 } & \multirow{2}{*}{ 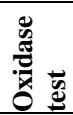 } \\
\hline & slant & butt & gas & $\mathbf{H}_{2} \mathrm{~S}$ & & & & & & \\
\hline Escherichia coli & $\mathrm{Y}$ & $\mathrm{Y}$ & + & - & - & - & - & + & + & - \\
\hline Klebsiella spp. & $\mathrm{Y}$ & Y & + & - & - & - & + & + & + & - \\
\hline Pseudomonas spp. & $\mathrm{R}$ & $\mathrm{R}$ & - & - & - & - & - & + & - & - \\
\hline Staphylococcus spp. & $\mathrm{Y}$ & $\mathrm{R}$ & + & + & - & + & - & + & + & - \\
\hline Bacillus spp. & $\mathrm{Y}$ & $\mathrm{Y}$ & - & - & - & - & + & + & + & - \\
\hline Listeria spp. & Y & Y & - & - & - & + & + & - & + & - \\
\hline Salmonella spp. & $\mathrm{R}$ & $\mathrm{Y}$ & - & + & - & + & - & - & + & - \\
\hline
\end{tabular}


Klebsiella spp., Staphylococcus spp., Bacillus spp., and Listeria spp. found in all samples within a range of $10^{2}$ to $10^{3} \mathrm{cfu} / \mathrm{g}$. Fecal coliform, Pseudomonas spp. and Salmonella spp. were found to be present in only two samples and Vibrio spp. could not be isolated in any sample. On the other hand, super shop vegetables harbored only Escherichia coli, Staphylococcus spp., and Pseudomonas spp. within a range of $10^{2}$ to $10^{3}$ $\mathrm{cfu} / \mathrm{g}$. However, fecal coliform, Bacillus spp. Listeria spp., Salmonella spp., and Vibrio spp. are totally absent in all samples collected from super shops.

Highest total coliform $\left(4.8 \times 10^{3} \mathrm{cfu} / \mathrm{g}\right)$ was found in Green Chili of local market whereas lowest $3.0 \times 10^{2}$ $\mathrm{cfu} / \mathrm{g}$ count was found in coriander of super shop. Similarly, highest count $\left(8.0 \times 10^{2} \mathrm{cfu} / \mathrm{g}\right)$ of fecal coliform was found in coriander of local market whereas absent in super shop samples. The presence of total coliform in the food sample indicates the presence of fecal materials which is definite by the presence of E. coli.

Comparison of vegetables quality collected from local markets and super shops. Microbiological quality of vegetable sold in local markets and super shops were found to be different in our research. Many pathogenic bacteria and fungi were found in most of the samples collected from local markets and super shops. Total viable bacterial count was greater in both samples of local markets than super shops samples. In the case of fecal coliform count, local market samples showed unacceptable results whereas super shop samples showed no count. Similarly total coliform, S. aureus, Bacillus spp., Pseudomonas spp., Listeria spp., Salmonella spp., Shigella spp. and vibrio spp. showed huge count in local market vegetables whereas the same samples of super shops showed very limited count and some of these microorganisms showed no growth. Since almost all microbial counts were found greater in samples (Lady Finger, Coriander Green Chili and Tomato) collected from local markets than the similar samples from super shops.

Antibiogram of the bacterial isolates. Six presumptively identified Staphylococcus spp. from blood agar plates were selected for the determination of antibiotic sensitivity pattern against six different types of antibiotics. The results are shown in Table 4. Upon antibiogram profiling, it was clearly evident that Staphylococcus spp. were mostly resistant against Cotrimoxazole (84\%) and highly sensitive to Vancomycin (100\%) and Ciprorofloxacin (100\%). Mixed sensitivity was observed against Amoxicillin (50\%), Chloramphenicol (67\%) and Erythromycin $(50 \%)$

\section{DISCUSSION}

The present investigation of vegetables (Lady Finger, Coriander Green Chili and Tomato) quality was different in both local markets and super shops in Dhaka city. The most contaminated vegetable was coriander from both local markets and super shops. Moreover, in every vegetable sample, almost all pathogenic microorganisms such as Escherichia coli, Klebsiella spp., fecal coliform, fungi, Staphylococcus aureus, Bacillus spp., Pseudomonas spp., Listeria spp., Salmonella spp., Shigella spp., and Vibrio spp. were found in undesirable amounts (38). The presence of Staphylococcus spp. in both categories of shops may be introduced from food handlers. The presence of other pathogenic bacteria like Listeria spp. and Salmonella spp. in the vegetables of local markets is of public health concern.

Previous study by Rahman et al. and Ahmed et al. found similar results and these microorganisms could cause various food-borne diseases such as food poisoning, diarrhea, dysentery, cholera as well as typhoid \& pneumonia $(24,26)$. Raw vegetables were not safe to eat without processing or cooking, so, before eating as salad or food, these vegetables must be washed properly with clean water or other recommended washing methods $(24,27)$.

Moreover, bacteria isolated in this study may be part of the natural flora of the vegetables or contaminants from the pre and post-harvesting stage like air, water, cultivated soil, pots or places where vegetables kept, shopkeeper's as well as customer's hands, hair, dresses, etc. (28-31). Since local markets were placed in an open place which were congested and dirty, so vegetables could easily get contaminated from air, water and surround environments $(34,35)$. On the other hand, super shops were placed in closed building which was comparatively clean likewise supermarket salesman's were more carefully maintained almost all hygienic rules before handling vegetables to prevent microbial contaminations $(36,37)$. So, government needs to give more attention in inspection on the local markets and organize some free session to literate vegetables handler about hygienic handling practice.

\section{CONCLUSION}

The presence of pathogenic bacteria contamination in fresh vegetables is not desirable, in any condition which may cause food-borne illness in human. That is why, GHP, GAP, and HACCP need to be introduced to avoid contamination. On the other hand, Government should take some necessary steps in the agriculture sector to reduce the health risk factors by foodborne illness. In conclusion, we found that four samples of vegetables (Green Chili, Tomato, Lady Finger and Coriander) under study were more or less contaminated but a comparatively higher load in local market samples indicated that the hygienic condition of these markets was poor. Our study thus reported not only a complete scenario on the microbial profile of the common vegetables from local and super shops but also compared their results.

\section{ACKNOWLEDGEMENTS}

Authors are thankful to the Department of Microbiology, Stamford University Bangladesh for the technical supports provided during the study. 


\section{REFERENCES}

1. Abadias M, Usall J, Anguera M, Solsona C and Viñas I. 2008 Microbiological quality of fresh, minimally-processed fruit and vegetables, and sprouts from retail establishments. Int. J. Food Microbiol. 123(1-2):121-129.

2. Heaton JC and Jones K. 2007. Microbial contamination of fruit and vegetables and the behavior of enteropathogens in the phyllosphere: a review. J. App. Micro. 104(3):613-626.

3. Alam MS, Feroz F, Rahman H, Das KK and Noor R. 2015. Microbiological contamination sources of freshly cultivated vegetables. Nutr. Food Sci. 45(4):646-658

4. Adjrah Y, Soncy K, Anani K, Blewussi K, Karou DS, Ameyapoh Y et al. 2013. Socio-economic profile of street food vendors and microbiological quality of ready-to-eat salads in Lomé. Int. Food Res. J. 20(1):65.

5. Rekhy R and McConchie R. 2014. Promoting consumption of fruit and vegetables for better health. Have campaigns delivered on the goals? Appetite. 79:113-123.

6. Wang X, Ouyang Y, Liu J, Zhu M, Zhao G, Bao W et al. 2014. Fruit and vegetable consumption and mortality from all causes, cardiovascular disease, and cancer: systematic review and doseresponse meta-analysis of prospective cohort studies. Br. Med. J. 349:g4490.

7. Ahmed T, Urmi NJ, Munna MS, Das KK, Acharjee M, Rahman MM et al. 2014. Assessment of microbiological proliferation and in vitro demonstration of the antimicrobial activity of the commonly available salad vegetables within Dhaka metropolis, Bangladesh. Am. J. Agri. Fore. 2(2):55-60.

8. Aycicek H, Oguz U and Karci K. 2006. Determination of total aerobic and indicator bacteria on some raw eaten vegetables from wholesalers in Ankara, Turkey. Int. J. Hyg. Environ. Health 209(2):197-201.

9. Callejón RM, Rodríguez-Naranjo MI, Ubeda C, Hornedo-Ortega R, Garcia-Parrilla MC and Troncoso AM. 2015. Reported foodborne outbreaks due to fresh produce in the United States and European Union: trends and causes. Foodborne Pathog. Dis.12:32-38.

10. Feroz F, Senjuti JD and Noor R. 2013. Determination of microbia growth and survival in salad vegetables through in vitro challenge test. Int. J. Nutri. Food Sci. 2(6):312-319.

11. Senjuti JD, Feroz F, Tahera J, Das KK and Noor R. 2014. Assessment of microbiological contamination and the in vitro demonstration of the anti-bacterial traits of the commonly available local fruit blend within Dhaka Metropolis. J. Pharmacogn. Phytochem. 3(1):73-77.

12. Nawas T, Mazumdar RM, Das S, Nipa MN, Islam S, Bhuiyan $\mathrm{H}$ et al 2012. Microbiological quality and antibiogram of E. coli, Salmonell and Vibrio of salad and water from restaurants of Chittagong. J. Env. Sci. Nat. Res. 5(1):159-166.

13. Nipa MN, Mazumdar RM, Hasan MM, Fakruddin M, Islam S, Bhuiyan HR et al. 2011. Prevalence of MultiDrug Resistant Bacteria on Raw Salad Vegetables Sold in Major Markets of Chittagong City, Bangladesh. Middle East J. Sci. Res. 10(1):70-11.

14. Bibek R. 2005. Fundamental of Food Microbiology, CRC press, Boca Raton: London New York Washington D.C.

15. Kadariya J, Smith TC and Thapaliya D. 2014. Staphylococcus aureus and staphylococcal food-borne disease: an ongoing challenge in public health. BioMed. Res. Int. 2014:827965.

16. Bao Z, Ikunaga Y, Matsushita Y, Morimoto S, Takada-Hoshino Y, Okada $\mathrm{H}$ et al. 2012. Combined analyses of bacteria, fungal and nematode communities in and osolic agricultural soils in Japan. Microbes Env. 27(1):72-79.

17. Hawkins P, Blackett I and Heymans C. 2013. Poor-Inclusive Urban Sanitation: An Overview. Water and Sanitation Program, World Bank, Washington, DC

18. Dufour A, Bartram J, Bos R and Gannon V. 2012. Animal Waste, Water Quality and Human Health, IWA Publishing, London.

19. Hanjra MA, Blackwell J, Carr G, Zhang F and Jackson TM. 2012 Wastewater irrigation and environmental health: implications for water governance and public policy. Int. J. Hyg. Env. Health 215(3):255-269.
20. Qadir M, Wichelns D, Raschid-Sally L, McCornick PG, Drechsel P, Bahri A et al. 2010. The challenges of waste- water irrigation in developing countries. Agric. Water Manag. 97(4):561-568.

21. American Public Health Association (APHA), 1998. Standard methods for the examination of water and wastewater. American Public Health Association, Washington, D.C.

22. Cappuccino JG and Sherman N. 2005. Microbiology: A laboratory manuals. 7th ed. USA: Benjamin Cummings Publishing Co., Inc., Menlo Park, California.

23. Ahmed S, Siddique MA, Rahman M, Bari ML and Ferdousi S. 2019. A study on the prevalence of heavy metals, pesticides, and microbial contaminants and antibiotics resistance pathogens in raw salad vegetables sold in Dhaka, Bangladesh. Heliyo. 5(2):e01205.

24. Rahman H, Feroz F, Alam MS, Das KK and Noor R. 2016 Demonstration of the source of microbial contamination of freshly cultivated cabbage, cauliflower, potato and squash collected from rural farms of Bangladesh. Int. Food Res. J. 23(3):1289-1295.

25. Butt AA, Aldridge KE and Sanders CV. 2004. Infections related to the ingestion of seafood part 1: viral and bacterial infections. Lancet Infect. Dis. 4:201-212.

26. Oni V, Oni A and Esumeh F. 2009. Prevalence of Bacteria food poison from vegetable salads. Internet J. Nutr. Wellness 10(1).

27. Feroz F, Das KK and Islam T. 2020. Comparison of commercially available food decontaminants with established methods of decontamination for household practices which are used to keep foods safe. Food Res. 4(5):1688-1692.

28. Mandrell RE. 2009. Enteric human pathogens associated with fresh produce: sources, transport, and ecology, in Microbial Safety of Fresh Produce, eds X. Fan, B. Niemira, C. J. Doona, F. Feeherry, and R. B. Gravani (Ames, IA: IFT Press/Wiley-Blackwell Publishing), 5-41.

29. Talley JL, Wayadande AC, Wasala LP, Gerry AC, Fletcher J, DeSilva $\mathrm{U}$ et al. 2009. Association of Escherichia coli O157:H7 with filth flies (Muscidae and Calliphoridae) captured in leafy greens fields and experimental transmission of E. coli O157:H7 to spinach leaves by house flies. J. Food Prot. 72:1547-1552.

30. Mishra A, Guo M, Buchanan RL, Schaffner DW and Pradhan AK. 2017. Development of growth and survival models for Salmonella and Listeria monocytogenes during non-isothermal time-temperature profiles in leafy greens. Food Control 71:32-41.

31. Ofor MO, Okorie VC, Ibeawuchi II, Ihejirika GO, Obilo OP and Dialoke SA. 2009. Microbial Contaminants in Fresh Tomato Wash Water and Food Safety Considerations in South-Eastern Nigeria. Life Sci. J. 1:80-82.

32. Colwell RR. 2000. Bacterial death revisited. In: Non-culturable microorganisms in the environment, Colwell RR and Grimes DJ (Eds), pp. 325-342. American Soc. Microbiol., Washington DC, USA.

33. Oliver JD. 2000. The public health significance of viable but nonculturable bacteria. In: Non-culturable microorganisms in the environment, Colwell RR and Grimes DJ (Eds), pp. 277-300. American Soc. Microbiol., Washington DC, USA.

34. Saranraj P, Stella D and Reetha D. 2012. Microbial spoilage of vegetables and its control measures: a review. Int. J. Nat. Product Sci. 2(2):1-12.

35. Tournas VH. 2005. Moulds and yeasts in fresh and minimally processed vegetables and sprouts. Int. J. Food Micro. 99(1):71-77.

36. Masum MS, Amin MR and Faruky KNB. 2012. Green Marketing for Agricultural Products Offered by Super Shops in Bangladesh. World J. Social Sci. 2(5):161-183.

37. Khanom A, Shammi $T$ and Kabir MS. 2016. Determination of microbiological quality of packed and unpacked bread. Stam J. Microbiol. 6(1):24-29.

38. Institute of Medicine (US) and National Research Council (US) Committee on the Review of the Use of Scientific Criteria and Performance Standards for Safe Food. 2003. Scientific Criteria to Ensure Safe Food. Washington (DC): National Academies Press (US); Appendix E, Inte Micro Criteria. Available at: https://www.ncbi.nlm.nih.gov/books/NBK221566/. 